\title{
New austrolimulid from Russia supports role of early Triassic horseshoe crabs as opportunistic taxa
}

\author{
Russell D Bicknell ${ }^{\text {Corresp., } 1}$, Dmitry E Shcherbakov ${ }^{2}$ \\ 1 Palaeoscience Research Centre, School of Environmental and Rural Science, University of New England, Armidale, NSW, Australia \\ 2 Borissiak Paleontological Institute, Russian Academy of Sciences, Moscow, Russia \\ Corresponding Author: Russell D Bicknell \\ Email address: rdcbicknell@gmail.com
}

Horseshoe crabs are extant marine euchelicerates that have a fossil record extending well into the Palaeozoic. Extreme xiphosurid morphologies arose during their evolutionary history. These forms often reflected the occupation of freshwater or marginal conditions. This is particularly the case for Austrolimulidae-a xiphosurid family that has recently been subject to thorough taxonomic examination. Expanding the austrolimulid record, we present new material from the Olenekian-aged Petropavlovka Formation in European Russia and assign this material to Attenborolimulus superspinosus gen. et sp. nov. A geometric morphometric analysis of 23 horseshoe crab genera illustrates that the new taxon is distinct from limulid and paleolimulid morphologies, supporting the assignment within Austrolimulidae. In considering Triassic austrolimulids, we suggest that these bizarre forms with hypertrophied or reduced exoskeletal sections illustrate that species within the family functioned as opportunistic taxa after the end-Permian extinction. 
1 New austrolimulid from Russia supports role of early Triassic horseshoe crabs as

2 opportunistic taxa

3 Russell D. C. Bicknell ${ }^{1,{ }^{*}}$ and Dmitry E. Shcherbakov ${ }^{2}$

$4{ }^{1}$ Palaeoscience Research Centre, School of Environmental and Rural Science, University of New

5 England, Armidale, New South Wales, 2351, Australia.

$6{ }^{2}$ Borissiak Paleontological Institute, Russian Academy of Sciences, Profsoyuznaya St 123,

7 Moscow 117647, Russia.

$8 \quad$ *Corresponding author, email: rdcbicknell@gmail.com. 


\section{Abstract}

11 Horseshoe crabs are extant marine euchelicerates that have a fossil record extending well into the

12 Palaeozoic. Extreme xiphosurid morphologies arose during their evolutionary history. These

13 forms often reflected the occupation of freshwater or marginal conditions. This is particularly the

14 case for Austrolimulidae - a xiphosurid family that has recently been subject to thorough

15 taxonomic examination. Expanding the austrolimulid record, we present new material from the

16 Olenekian-aged Petropavlovka Formation in European Russia and assign this material to

17 Attenborolimulus superspinosus gen. et sp. nov. A geometric morphometric analysis of 23

18 horseshoe crab genera illustrates that the new taxon is distinct from limulid and paleolimulid

19 morphologies, supporting the assignment within Austrolimulidae. In considering Triassic

20 austrolimulids, we suggest that these bizarre forms with hypertrophied or reduced exoskeletal

21 sections illustrate that species within the family functioned as opportunistic taxa after the end-

22 Permian extinction.

23 Keywords: Xiphosurida, end-Permian extinction, Triassic recovery, geometric morphometrics,

24 new species, exceptional preservation 

extinction) during the Triassic is important for understanding how biological systems can redevelop after major devastating events (Erwin et al., 2002; Jablonski, 2002; Payne et al., 2004; Twitchett et al., 2004; Dineen et al., 2014). Triassic vertebrate (Hu et al., 2011; Chen \& Benton, 2012; Benton et al., 2013; Tintori et al., 2014; Fu et al., 2016), invertebrate (Rodland \& Bottjer, 2001; Hu et al., 2011; Chen \& Benton, 2012; Hofmann et al., 2013; Fu et al., 2016; Ponomarenko, 2016), and trace (Chen et al., 2012; Crasquin \& Forel, 2014; Luo \& Chen, 2014; Luo et al., 2019, 2020; Shi et al., 2019; Xing et al., 2021) fossil assemblages have been examined to understand recovery of the distinct palaeoecological facets. The arthropod record in particular has shed light on how marine and terrestrial groups recovered after the end-Permian. Ostracods (Crasquin-Soleau et al., 2007; Forel, 2012; Forel et al., 2013; Crasquin \& Forel, 2014; Chu et al., 2015) and insects (Gall \& Grauvogel-Stamm, 2005; Shcherbakov, 2008a, b; Hu et al., 2011; Żyła et al., 2013; Ponomarenko, 2016; Zheng et al., 2018) are commonly examined, with rarer studies of branchiopods (Żyła et al., 2013) and horseshoe crabs (Gall \& Grauvogel-Stamm, 2005; Hu et al., 2011; Lerner et al., 2017; Bicknell et al., 2019b; 2021b). The record of Triassic xiphosurids Lerner et al., 2017; Bicknell et al., 2019a, b, 2021a; Bicknell \& Pates, 2020; Lamsdell, 2020). (so-called horseshoe crabs) has recently been scrutinised; a research trajectory that has uncovered a wealth of data on post-Permian taxa (see Błażejowski et al., 2017; Hu et al., 2017; Two xiphosurid families are known from the Triassic: Austrolimulidae and Limulidae (Table 1). Of these two, austrolimulids are predominantly marginal marine to freshwater forms that commonly exhibit hypertrophied or reduced features. Here, we present new horseshoe crab material from the Konservat Lagerstätte within the Petropavlovka Formation, Cis-Urals of 
48 Russia to promote the study of Austrolimulidae and their role in the Triassic recovery of

49 Xiphosurida. This material is also examined using geometric morphometrics to mathematically

50 illustrate the austrolimulid position of these fossils within xiphosurid morphospace. This

51 evidence, coupled with a thorough taxonomic consideration, prompted us to place the

52 Petropavlovka Formation material within a novel genus and species: Attenborolimulus

53 superspinosus gen. et sp. nov.

The Permian-Triassic succession of the Cis-Urals is well known for diverse fossil

tetrapods and stratigraphic sections that permit detailed study of changes in climate, landscapes, vegetation, and biological communities across the Permian-Triassic boundary (Ochev \& Shishkin, 1989; Shishkin et al., 1995; Benton et al., 2004; Gomankov, 2005; Shcherbakov, 2008a; Benton \& Newell, 2014; Shishkin \& Novikov, 2017). The Petropavlovka Formation within this important succession is considered upper Olenekian (251.2-247.2 Ma) based on the Parotosuchus Otschev \& Shishkin (in Kalandadze et al., 1968) tetrapod fauna, the lungfish Ceratodus multicristatus (Vorobyeva \& Minikh, 1968), miospore assemblages rich in Densoisporites nejburgii associated with the lycophyte Pleuromeia, and magnetostratigraphy (Figure 1A; Shishkin et al., 1995; Minikh \& Minikh, 1997; Tverdokhlebov et al., 2003). During the Olenekian, orogenic development occurred in the Ural Mountains, while the Peri-Caspian Depression was inundated by the transgression of the Palaeotethys. This resulted in increased rates of siliciclastic deposition in the Cis-Urals (Tverdokhlebov, 1987). In the Cis-Ural Trough and southeastern slope of the Volga-Ural Anteclise, a vast lacustrine-deltaic floodplain was formed. This bordered the northern Peri-Caspian marine basin of the Palaeotethys. The Petropavlovka Formation accumulated in this floodplain. The formation consists of grey and 
71 reddish-grey siliciclastics. It is primarily a rhythmic alternation of coarse- and fine-grained

72 sandstone, clay, siltstone, and fine-grained clayey sandstone, reaching a total thickness of 400-

73

74

75

76

77

78

79

80

81

82

83

84

85

86

87
$800 \mathrm{~m}$ (Shishkin et al., 1995). Conglomerate lenses are also common. Coarser sediment

represents alluvial deposits, while finer lithologies constitute shallow water lacustrine deposits.

These facies characterise the delta floodplain and delta front complexes that comprise the

Petropavlovka Formation (Tverdokhlebov et al., 2003).

The Petropavlovka Formation stratotype section occurs along the Sakmara River and adjacent ravines close to Petropavlovka $\sim 45 \mathrm{~km}$ north-east of Orenburg (52 $\left.02^{\prime} \mathrm{N}, 55^{\circ} 38^{\prime} \mathrm{E}\right)$. Red beds exposed here yield tetrapods, lungfish, clam shrimps (conchostracans), and ostracods (Shishkin et al., 1995). Along one ravine, a one-meter-thick lens of grey fine-grained polymictic siltstone to sandstone was identified (locality Petropavlovka III, bed 43; Tverdokhlebov, 1967).

The lens contains abundant plant megafossils including sphenophytes and gymnosperms (Dobruskina, 1994). In 2018-2019 numerous diverse insects wings, millipedes, horseshoe crabs, microconchids, and a microdrile oligochaete were collected in the lens, along with seed fern pinnules and lycophyte fragments (Hannibal \& Shcherbakov, 2019; Shcherbakov et al., 2020, 2021).

\section{Materials \& Methods}

The studied specimens were collected by the field parties of, and are housed in, the Borissiak Paleontological Institute (PIN), Russian Academy of Sciences, Moscow, Russia. The material was photographed with a Nikon D800 camera mounted with a Nikon AF-S ED Micro Nikkor 60mm f/2.8G lens. Images were z-stacked with Helicon Focus Pro 6.7. Furthermore, a Leica DFC425 camera coupled to Leica M165C stereomicroscope was used. Finally, to examine possible evidence for finer structures, specimens were examined under a TESCAN VEGA

Peer] reviewing PDF | (2021:03:59506:1:1:NEW 22 May 2021) 
94 scanning electron microscope (SEM) housed at the PIN. A backscattered electron detector was

95 used as the specimens were not coated.

96

97

98

99

100

101

102

103

104

105

106

107

108

109

110

111

112

113

114

115

116

When describing the material, we followed the systematic taxonomy of Bicknell \& Pates (2020) and Bicknell et al. (2021a) and used anatomical terms presented in Lerner et al. (2017), Bicknell (2019) and Bicknell et al. (2020, 2021a).

The geometric morphometric analysis presented here develops on recent applications by Bicknell (2019), Bicknell \& Pates (2019), Bicknell et al. (2019b), and Lustri et al. (2021). The approach was used to assess where the Petropavlovka Formation material falls in xiphosurid morphospace and allows for a mathematical comparison with other xiphosurid specimens, augmenting the taxonomic description presented here. A total of 103 specimens arrayed across 23 genera from Austrolimulidae, Limulidae, and Paleolimulidae (sensu Bicknell \& Pates, 2020) were considered. Landmarking and semilandmarking was conducted with the Thin-Plate Spline (TPS) suite (http://life.bio.sunysb.edu/morph/index.html). A TPS file was constructed using tpsUtil64 (v.1.7). The TPS file was imported into tpsDig2 (v.2.26). This software was used to place four landmarks on the right prosomal section, as well as 50 semi-landmarks along the right prosomal shield border (Figure 2, Supplementary Table 1). Points were digitised as $x y$ coordinates. When the right side was poorly preserved, the left side was used, and data mirrored. These points populated the TPS file with landmark data (Supplementary Information 1). The TPS file was imported into R. The 'geomorph' package (Adams et al., 2020) was used to conduct a Procrustes Superimposition and Principal Components Analysis (PCA) of the data (Supplementary Information 2). Only the first two Principal Components (PCs) were considered as they explain $75.6 \%$ of the variation in the data (Supplementary Information 3). Bicknell et al. (2019b) demonstrated that the distribution in PC space reflects biological variation. As such, 
117 while preservational mode varies between specimens (consider Bicknell \& Pates, 2020), this

118 variation has little impact on the morphospace (see discussion in Lustri et al., 2021). The generic

119 and family assignments presented in Supplemental Information 3 reflect a combination of

120 taxonomic theses presented in Bicknell \& Pates (2020), Lamsdell (2020), and Bicknell et al.

121 (2021a).

The electronic version of this article in Portable Document Format (PDF) will represent a published work according to the International Commission on Zoological Nomenclature (ICZN),

124 and hence the new names contained in the electronic version are effectively published under that

125 Code from the electronic edition alone. This published work and the nomenclatural acts it

126 contains have been registered in ZooBank, the online registration system for the ICZN. The

127 ZooBank LSIDs (Life Science Identifiers) can be resolved and the associated information viewed

128 through any standard web browser by appending the LSID to the prefix http://zoobank.org/. The

129 LSID for this publication is: 5435A6BA-AE34-4698-8872-7A350DB799B1. The online version

130 of this work is archived and available from the following digital repositories: PeerJ, PubMed

131 Central and CLOCKSS.

\section{Systematic Palaeontology}

Etymology: The generic name is given in honour of Sir David Attenborough and his unparalleled contributions to natural history and conservation. His last name is combined with

137 Limulus - the most-well documented extant xiphosurid genus.

138 Type species: Attenborolimulus superspinosus, new species. 
139 Diagnosis. Austrolimulid with anteriorly effaced, ridge-less cardiac lobe, slightly splayed genal

140 spines extending posteriorly to three-fourths of thoracetron length with occipital bands extending

141 to spine terminus, tubercle structures along posterior prosomal and anterior thoracetronic border,

142 medial thoracetronic lobe lacking a sagittal ridge, and long, strongly keeled telson.

Figures 3-8

Etymology: Species name reflects the hypertrophied (super-) genal spine (-spinosus) morphology.

Holotype: PIN 5640/220 (part and counterpart).

Paratypes: PIN 5640/217, PIN 5640/200 (part and counterpart).

Type locality and horizon. Petropavlovka III near the village of Petropavlovka, Orenburg region, Russia; Petropavlovka Formation, upper Olenekian, Lower Triassic.

Diagnosis. Same as for genus.

Preservation. Specimens are preserved as partly domed exoskeletons as part and counterpart on yellowish or grey siltstone.

Description. PIN 5640/220 (part and counterpart): An articulated prosoma, thoracetron, and distally incomplete telson (Figures 3-5). Specimen is $32.0 \mathrm{~mm}$ long as preserved. Prosoma parabolic in outline, $9.8 \mathrm{~mm}$ long at midline, and $15.3 \mathrm{~mm}$ wide between genal spine tips. Exoskeletal warping along anterior and left lateral prosomal sections. Prosomal rim $0.2 \mathrm{~mm}$ wide. Prosomal doublure $1.6 \mathrm{~mm}$ wide laterally, arcuately widened to $2.5 \mathrm{~mm}$ medially. Ophthalmic ridges curved towards the lateral prosomal border, $\sim 4.5 \mathrm{~mm}$ long. Ridges do not 160 converge anteriorly. Lateral compound eyes narrow and reniform, $\sim 2.9 \mathrm{~mm}$ long, $\sim 0.7 \mathrm{~mm}$ wide, 161 inner orbita $4.1 \mathrm{~mm}$ from midline. Cardiac lobe $7.5 \mathrm{~mm}$ long, $4.1 \mathrm{~mm}$ wide posteriorly, tapering 
162 to its mid-length, about $2.0 \mathrm{~mm}$ wide in anterior half, tapered to $1.4 \mathrm{~mm}$ near apex, effaced

163 anteriorly. Break in left genal spine within first quarter of thoracetron. Posterior-most left genal

164 section $8.4 \mathrm{~mm}$ from midline. Angle between inner edge of left genal spine and left thoracetron

165 side $77.2^{\circ}$. Right genal spine complete, terminates three fourths along thoracetron. Genal spine

166 terminus $7.8 \mathrm{~mm}$ from midline, $6.9 \mathrm{~mm}$ from level of prosomal-thoracetronic hinge. Angle

167 between right inner edge of genal spine and right thoracetron side $38.5^{\circ}$. Pronounced occipital

168 bands extend from ophthalmic ridges to genal spine ends. Prosomal-thoracetronic hinge

169 pronounced, $7.6 \mathrm{~mm}$ wide, and $0.6 \mathrm{~mm}$ long. Posterior prosomal border with shallow central

170 notch $2.1 \mathrm{~mm}$ wide. Distal sections of prosomal appendages noted lateral to compound eyes

171 (Figure 3B).

173 long at midline, $9.4 \mathrm{~mm}$ wide anteriorly, tapering to $4.7 \mathrm{~mm}$ posteriorly. Tubercle structures

174 along anterior thoracetron border noted under SEM (Figure 5D). Thoracetronic flange present.

175 Rounded anterolateral lobes apparently present. Setose margins of branchial appendages

176 (opercula) visible anteriorly on left side in counterpart. Medial thoracetronic lobe weakly

177 defined, $7.3 \mathrm{~mm}$ long, $3.0 \mathrm{~mm}$ anteriorly, tapering to $1.2 \mathrm{~mm}$ posteriorly. Lobe lacking medial

178 thoracetronic ridge. Left pleural lobe has $0.3 \mathrm{~mm}$ wide rim. Left lobe $8.0 \mathrm{~mm}$ long, $2.6 \mathrm{~mm}$ wide, 179 tapering posteriorly to short, round terminal spine. Right lobe damaged in part. Measurements 180 taken from counterpart. Right lobe $8.2 \mathrm{~mm}$ long, $2.5 \mathrm{~mm}$ wide, tapering posteriorly to short, 181 rounded terminal spine. Minute fixed spines and movable spine notches observed under SEM on 182 left side of thoracetron (Fig. 5C). Telson $14.1 \mathrm{~mm}$ long as preserved, with well-developed keel.

183 Telson terminates at rock edge, has a kink at a third of the spine length. 
PIN 5640/200 (part and counterpart): Isolated prosoma preserved more completely in part 185 (Figures 5B, 6). Prosoma parabolic in outline, $15.1 \mathrm{~mm}$ long at midline, and $28.0 \mathrm{~mm}$ wide

between most distal genal spine points. Exoskeletal warping along anterior and right lateral prosomal sections. Prosomal rim $0.6 \mathrm{~mm}$ wide. Prosomal doublure $2.1 \mathrm{~mm}$ wide, arcuately widened backwards up to $4.1 \mathrm{~mm}$ medially. Right ophthalmic ridge noted in counterpart (Figure 6C, D). Ridge curved towards the lateral prosomal border, $9.1 \mathrm{~mm}$ long. Lateral compound eyes narrow reniform, $\sim 3.7 \mathrm{~mm}$ long, $\sim 0.8 \mathrm{~mm}$ wide, right inner orbita $7.5 \mathrm{~mm}$ from midline. Cardiac lobe present, $7.5 \mathrm{~mm}$ long, $6.8 \mathrm{~mm}$ wide posteriorly, tapering (posteriorly to anteriorly) to 1.8 $\mathrm{mm}$, effaced anteriorly. Left genal spine broken distally. Most distal left genal section $13.9 \mathrm{~mm}$ from midline. Right genal spine complete, lateral margin slightly convex. Genal spine terminus $14.1 \mathrm{~mm}$ from midline, $13.6 \mathrm{~mm}$ from prosomal-thoracetronic hinge. Pronounced occipital bands extend from ophthalmic ridges to genal spine ends, better preserved along right genal spine.

Ridge delimiting occipital band with tubercles along posterior prosomal border and near base of genal spines. Posterior prosomal border with arcuate central notch $4.3 \mathrm{~mm}$ wide. Clam shrimp (round structures) noted.

PIN 5640/217: Central and left side of prosoma (Figure 7), $15.4 \mathrm{~mm}$ long at midline, and $17.1 \mathrm{~mm}$ wide at widest section. Prosomal rim $0.3 \mathrm{~mm}$ wide. Partial left ophthalmic ridge noted. Cardiac lobe $9.0 \mathrm{~mm}$ long, $7.0 \mathrm{~mm}$ wide posteriorly, tapering slightly anteriorly to $2.5 \mathrm{~mm}$, effaced anteriorly. Anterior most section of left genal spine noted. Two tentaculitoid tubeworms noted on left side of prosoma (round structures; Shcherbakov et al., 2021).

Remarks: The horseshoe crab material documented herein displays hypertrophied genal spines, a feature common in Belinurina and Austrolimulidae. The examined material lacks the expression of thoracetronic tergites extending from the medial lobe to the thoracetron edge and a 
207 rounded thoracetron common to Belinurina. This suggests the material likely belong within

208 Austrolimulidae. Bicknell et al. (2020) outlined two major groupings of austrolimulids: those

209 with reduced thoracetronic sections relative to the prosoma and those with genal spines that

210 extend up to the thoracetron terminus. Prosomal and thoracetronic sections of the Petropavlovka

211 Formation specimens are comparable, excluding this material from the first group Bicknell et al.

212 (2020) outlined. This differentiates the material considered here from, Batracholimulus

213 fuchsbergensis (Hauschke \& Wilde, 1987), Boeotiaspis longispinus (Schram, 1979),

214 Dubbolimulus peetae Pickett, 1984, Panduralimulus babcocki Allen \& Feldmann, 2005, and

215 Shpineviolimulus jakovlevi (Glushenko \& Ivanov, 1961). Comparisons to Austrolimulus fletcheri

216 Riek, 1955, Franconiolimulus pochankei Bicknell, Hecker \& Heyng, 2021, Psammolimulus

217 gottingensis Lange, 1923, Tasmaniolimulus patersoni Bicknell, 2019, and Vaderlimulus tricki

218 Lerner, Lucas \& Lockley, 2017 are therefore needed as they are austrolimulids with

219 hypertrophied genal spines. Austrolimulus fletcheri and $V$. tricki both have hypertrophied genal

220 spines with extensive splay, not observed in the Petropavlovka Formation material (Riek, 1955,

221 1968; Lerner et al., 2017). Franconiolimulus pochankei, the youngest austrolimulid, has a

222 cardiac ridge, distally effaced occipital bands, and a thoracetronic free lobe, none of which are

223 observed in the Petropavlovka Formation material. Tasmaniolimulus patersoni has pronounced

224 thoracetronic free lobes, as well as keeled cardiac and medial thoracetronic lobes (Ewington et

225 al., 1989; Bicknell, 2019). These are not observed in the Petropavlovka Formation material,

226 excluding the new fossils from this Lopingian (259.1-251.9 Ma) genus. Psammolimulus

227 gottingensis is the most morphologically similar to the new material. Indeed, the genal spine

228 morphology and pronounced occipital bands suggest a strong alignment with $P$. gottingensis

229 (Meischner, 1962). However, P. gottingensis has hypertrophied terminal thoracetronic spines and 
230 pronounced free lobes. Neither of these features are observed in the specimens examined here.

231 Based on this comparison, we assert that the Petropavlovka Formation material is

232 morphologically distinct from other austrolimulids enough to be separated at the generic level, as

233 Attenborolimulus superspinosus gen. et sp. nov. This taxonomic assessment is supported by

234 geometric morphometric results (see Results).

235

236

237

238

239

240

241

242

243

244

245

246

247

248

249

250

251

252

One point to consider is Limulitella Størmer, 1952 as an austrolimulid genus. Lamsdell (2020) recently used tree topology to propose that Limulitella fell into Austrolimulidae, suggesting that the family consisted of limuloids with "apodemal pits present on thoracetron; thoracetron lacking tergopleural fixed spines; posteriormost thoracetron tergopleurae swept back and elongated to form 'swallowtail'; axis of thoracetron bearing dorsal keel" (Lamsdell, 2020, p. 20). Examining L. bronnii (Schimper, 1853), for example, specimens have evidence of fixed spines, rendering the placement of Limulitella within Austrolimulidae tenuous. This perspective is supported by the position of Limulitella within morphospace that has consistently been closer to members of Limulidae of Paleolimulidae than Austrolimulidae (Bicknell, 2019; Bicknell et al., 2019; Bicknell and Pates, 2019; Figures 9, 10). It therefore seems more likely that Limulitella species represent a group of limulids, rather than austrolimulids (sensu Bicknell \& Pates, 2020; Bicknell et al., 2021a). At best, Limulitella may represent a transitional form between the two families. Finally, comparing the morphologies of Limulitella presented in Bicknell and Pates (2020, figs 28-30) to our material, the lack of hypertrophied genal spines separates this genus from Attenborolimulus superspinosus.

\section{Results}

The PCA plot illustrates that PC1 (48.3\% shape variation) describes how laterally the most distal genal spine point extends from the sagittal line (Figure 9). PC2 (27.3\% shape 
253 variation) describes how posteriorly the genal spine projects, relative to the prosomal sagittal line

254 and posterior border. Paleolimulids and limulids are both located in PC1 space $<0.05$, reflecting

255 the lack of genal splay observed in the groups. Specimens within Austrolimulidae cover PC1

256 space from $0-0.3$ reflecting the variation in genal spine splay observed in the family. The

257 holotype of Attenborolimulus superspinosus gen. et sp. nov. is located in a positive PC1 space

$258(\mathrm{PC} 1=0.099)$ and a neutral PC2 space $(\mathrm{PC} 2=0.002)$ (Figures 9, 10). It therefore falls outside the

259 morphospace occupied by Limulidae and Paleolimulidae (Figure 9) and within the morphospace

260 occupied by Austrolimulidae. However, it is distinct from the distribution of other austrolimulid 261 genera (Figure 10).

\section{Discussion}

The meter-thick lens that yielded Attenborolimulus gen. nov. is a rare occurrence of grey lithologies among the red beds of the Petropavlovka Formation. The red beds yield the lungfish

Ceratodus, temnospondyl amphibians, and procolophonid and erythrosuchid reptiles (Shishkin et al., 1995; Novikov, 2018). By comparison, the grey lens contain a different set of fossils: abundant, but fragmentary vascular plants, numerous insects (mainly isolated wings of various roaches, beetles, hemipterans, and rare dragonflies, grylloblattids, and orthopterans), microconchids, rare millipedes, and a microdrile oligochaete (Hannibal \& Shcherbakov, 2019; Shcherbakov et al., 2020, 2021). Clam shrimp and ostracods recorded in the grey bed occur in

271 surrounding red beds as well. Notably, plant and animal fossils are not restricted to certain

272 bedding planes but are randomly distributed in the rock, thus preserving some three-

273 dimensionality. Such sediment probably accumulated in an ephemeral pond during a flood event.

274 The millipedes, most plants, and nearly all insects were washed into the water body from the

275 land and are therefore allochthonous fossils. The horsetails Equisetites and Neocalamites likely 
276 grew as helophytes protruding out of the water as some fragments of their stems are encrusted

277 with microconchid shells. The aquatic ecosystem is represented by (sub)autochthonous fossils of

278 ceratodontid lungfishes, numerous schizophoroid beetle adults, clam shrimp, ostracods,

279 horseshoe crabs, microdriles, and microconchids. The microdrile specimens represent the earliest

280 fossil record of oligochaete annelids. This small worm is similar to modern tubificids, and its

281 relatively well-developed body wall musculature suggests that sediment burrowing was

282 originally another way to escape desiccation on the bottom of seasonally drying ponds

283 (Shcherbakov et al., 2020). Minute microconchids that encrusted plant stems, horseshoe crab

284 exuvia, and other available firm substrates represent the major suspension feeders in the

285 Petropavlovka ecosystem. These extinct lophophorates were genuine disaster taxa-eurytopic

286 stress-tolerators that flourished in the aftermath of the end-Permian extinction in both marine and

287 continental basins all over the world (Shcherbakov et al., 2021). Dense accumulations of

288 primarily pyrite dodecahedra are common on the plant stem fragments and attached

289 microconchid tubes. A high carbon/sulphur ratio might have produce abundant pyrite clusters in

290 a freshwater basin (Hethke et al., 2013). Also, the decomposition of organic matter by sulphate-

291 reducing bacteria favoured increased acidity and would lead to the precipitation of early

292 diagenetic pyrite (Fürsich \& Pan, 2016). This sedimentological feature might be indicative of

293 abundant decaying plant and animal remains consumed by bacteria at the lake bottom, but not for

294 the redox state of the water column itself. However, a lacustrine palaeocoenosis, including

295 ceratodontid lungfishes capable of aestivation in their burrows, horseshoe crabs, microdriles, and

296 abundant microconchids, strongly supports a meromictic eutrophic lake.

297 Vacant ecological space is a key factor in allowing evolutionary innovation to develop

298 (Erwin, 2008). Triassic austrolimulids capitalised on vacant marginal to freshwater environs left 
299 after the end-Permian extinction, thus exploiting an unprecedented array of niches and

300 representing 'disaster forms' (sensu Schubert \& Bottjer,1992). Triassic forms exhibit more

301 extreme morphologies than their Late Paleozoic counterparts (e.g., Panduralimulus babcocki,

302 Shpineviolimulus jakovlevi, and Tasmaniolimulus patersoni) suggesting that the morphological

303 stock required for Triassic diversification had arisen prior to the end-Permian (Bicknell, 2019).

304 The high xiphosurid Triassic diversity and disparity, followed by a constrained morphology and 305 generic level diversity from the Jurassic records the extinction of austrolimulids (Bicknell et al., $3062021 b$ ) and the transition to a morphology that was conserved through into modern ecosystems 307 (Bicknell \& Pates, 2020). The hypertrophied genal spines observed in austrolimulids also

308 illustrate evolutionary convergence with the Pennsylvanian-aged belinurids Euproops Meek, 3091867 and Belinurus Pictet, 1846. The prevalence of this trait in two distinct xiphosurid families 310 demonstrates how colonisation of marginal conditions placed similar evolutionary constraints on 311 the xiphosurid body plan, resulting in comparable morphologies.

\section{Declarations}

\section{Ethics Approval and Consent to Participate}

314 Not applicable.

\section{Consent for Publication}

316 Not applicable.

\section{Authors' Contributions}

RDCB conceived the project, developed the methods and wrote the first draft. DES collected and identified the fossils, and took photographs and collated other images and presented the 
320 geological and palaeontological information. Both authors constructed figures. Both authors

321 reviewed and edited the text.

This research was supported by funding from a University of New England Postdoctoral

Research Fellowship (to R.D.C.B.) and by the Russian Science Foundation grant 21-14-00284

(to D.E.S.). We are deeply grateful to Anastasia Felker, Elena Lukashevich, Olesya Strelnikova,

collecting, and especially to Eugeny Karasev who found the holotype, to Sergey Bagirov for the excellent photographs, to Roman Rakitov for his help in obtaining perfect SEM images, and to Andrey Sennikov (all PIN) and Valentin Tverdokhlebov (Saratov State University) for information on the fossil locality. We thank Nicolas E. Campione for discussions around the topic of disaster taxa. Finally, we thank Jason Dunlop, Joachim Haug, and Thomas Hegna for their comments that thoroughly improved the text.

\section{References}

Adams DC, Collyer ML, Kaliontzopoulou A. 2020. Geomorph: Software for geometric morphometric analyses. R package version 3.2.1. https://cranr-projectorg/package=geomorph: horseshoe crab from the Permian of Texas. Journal of Paleontology 79 (3): 594-600.

Benton MJ, Newell AJ. 2014. Impacts of global warming on Permo-Triassic terrestrial ecosystems. Gondwana Research 25 (4): 1308-1337. 
342 Benton MJ, Zhang Q, Hu S, Chen Z-Q, Wen W, Liu J, Huang J, Zhou C, Xie T, Tong J.

343 2013. Exceptional vertebrate biotas from the Triassic of China, and the expansion of marine

344 ecosystems after the Permo-Triassic mass extinction. Earth-Science Reviews 125: 199-243.

345 Bicknell RDC. 2019. Xiphosurid from the Upper Permian of Tasmania confirms Palaeozoic

346 origin of Austrolimulidae. Palaeontologia Electronica 22 (3): 1-13.

347 Bicknell RDC, Błażejowski B, Wings O, Hitij T, Botton ML. 2021a. Critical re-evaluation of

348 Limulidae reveals limited Limulus diversity. Papers in Palaeontology: 1-32, in press.

Bicknell RDC, Brougham T, Charbonnier S, Sautereau F, Hitij T, Campione NE. 2019a.

On the appendicular anatomy of the xiphosurid Tachypleus syriacus and the evolution of fossil horseshoe crab appendages. The Science of Nature 106 (7): 38.

Bicknell RDC, Hecker A, Heyng AM. 2021b. New horseshoe crab fossil from Germany demonstrates post-Triassic extinction of Austrolimulidae. Geological Magazine: 1-11, in press.

Bicknell RDC, Naugolnykh SV, Brougham T. 2020. A reappraisal of Paleozoic horseshoe crabs from Russia and Ukraine. The Science of Nature 107: 46.

Bicknell RDC, Pates S. 2019. Xiphosurid from the Tournaisian (Carboniferous) of Scotland confirms deep origin of Limuloidea. Scientific Reports 9 (1): 17102.

Bicknell RDC, Pates S. 2020. Pictorial atlas of fossil and extant horseshoe crabs, with focus on Xiphosurida. Frontiers in Earth Science 8 (98): 60.

Bicknell RDC, Žalohar J, Miklavc P, Celarc B, Križnar M, Hitij T. 2019b. A new limulid genus from the Strelovec Formation (Middle Triassic, Anisian) of northern Slovenia. Geological 362 Magazine 156 (12): 2017-2030. 
363 Błażejowski B, Niedźwiedzki G, Boukhalfa K, Soussi M. 2017. Limulitella tejraensis, a new

364 species of limulid (Chelicerata, Xiphosura) from the Middle Triassic of southern Tunisia

365 (Saharan Platform). Journal of Paleontology 91 (5): 960-967.

366 Bleicher M-G. 1897. Sur la découverte d'une nouvelle espèce de limule dans les marnes irisées

367 de Lorraine. Bulletin de la Societe des Sciences de Nancy 2: 116-126.

368 Braun KFW. 1860. Die Thiere in den Pflanzenschiefern der Gegend von Bayreuth.

369 Jahresbericht von der König Kreis-Landwirtschafts- und Gewerbschule zu Bayreuth für das

370 Schuljahr 1859/60:

371 Chen Z-Q, Benton MJ. 2012. The timing and pattern of biotic recovery following the end-

372 Permian mass extinction. Nature Geoscience 5 (6): 375-383.

373 Chen Z-Q, Fraiser ML, Bolton C. 2012. Early Triassic trace fossils from Gondwana Interior

374 Sea: implication for ecosystem recovery following the end-Permian mass extinction in south

375 high-latitude region. Gondwana Research 22 (1): 238-255.

376 Chu D, Tong J, Song H, Benton MJ, Song H, Yu J, Qiu X, Huang Y, Tian L. 2015. Lilliput

377 effect in freshwater ostracods during the Permian-Triassic extinction. Palaeogeography,

378 Palaeoclimatology, Palaeoecology 435: 38-52.

379 Crasquin-Soleau S, Galfetti T, Bucher H, Kershaw S, Feng Q. 2007. Ostracod recovery in the 380 aftermath of the Permian-Triassic crisis: Palaeozoic-Mesozoic turnover. Hydrobiologia 585: 1338127.

382 Crasquin S, Forel M-B. 2014. Ostracods (Crustacea) through Permian-Triassic events. Earth383 Science Reviews 137: 52-64. 
384 Dineen AA, Fraiser ML, Sheehan PM. 2014. Quantifying functional diversity in pre-and post-

385 extinction paleocommunities: a test of ecological restructuring after the end-Permian mass

386 extinction. Earth-Science Reviews 136: 339-349.

387 Dobruskina IA. 1994. Triassic Floras of Eurasia. Wien, New York: Springer.

388 Erwin DH. 2008. Extinction as the loss of evolutionary history. Proceedings of the National

389 Academy of Sciences 105 (Supplement 1): 11520-11527.

390 Erwin DH, Bowring SA, Yugan J. 2002. End-Permian mass extinctions: a review. In: Koeberl

391 C, and MacLeod KC, eds. Catastrophic Events and Mass Extinctions: Impacts and Beyond

392 Special Paper 356. Boulder: Geological Society of America, 363-384.

393 Ewington DL, Clarke MJ, Banks MR. 1989. A Late Permian fossil horseshoe crab

394 (Paleolimulus: Xiphosura) from Poatina, Great Western Tiers, Tasmania. Papers and

395 Proceedings of the Royal Society of Tasmania 123: 127-131.

396 Forel M-B. 2012. Ostracods (Crustacea) associated with microbialites across the Permian-

397 Triassic boundary in Dajiang (Guizhou Province, south China). European Journal of Taxonomy

398 19: 1-34.

399 Forel M-B, Crasquin S, Hips K, Kershaw S, Collin P-Y, Haas J. 2013. Biodiversity evolution

400 through the Permian—Triassic boundary event: Ostracods from the Bükk Mountains, Hungary.

401 Acta Palaeontologica Polonica 58 (1): 195-219.

402 Fu W, Jiang D-y, Montañez IP, Meyers SR, Motani R, Tintori A. 2016. Eccentricity and

403 obliquity paced carbon cycling in the Early Triassic and implications for post-extinction

404 ecosystem recovery. Scientific Reports 6 (1): 1-7.

405 Fürsich FT, Pan Y. 2016. Diagenesis of bivalves from Jurassic and Lower Cretaceous lacustrine 406 deposits of northeastern China. Geological Magazine 153 (1): 17-37. 
407 Gall J-C, Grauvogel-Stamm L. 2005. The early Middle Triassic 'Grès à Voltzia' Formation of 408 eastern France: a model of environmental refugium. Comptes Rendus Palevol 4 (6-7): 637-652.

409 Glushenko NV, Ivanov VK. 1961. Paleolimulus from the Lower Permian of the Donetz Basin. 410 Paleontologiceskij Žurnal 1961 (2): 128-130.

411 Gomankov AV. 2005. Floral changes across the Permian-Triassic boundary. Stratigraphy and 412 Geological Correlation 13 (2): 74-83.

413 Hannibal JT, Shcherbakov DE. 2019. New tomiulid millipedes from the Triassic of European

414 Russia and a re-evaluation of the type material of Tomiulus angulatus from the Permian of

415 Siberia. In: Dányi L, Korsós Z, and Lazányi E, eds. 18th International Congress of

416 Myriapodology: Hungarian Natural History Museum, Hungarian Biological Society. p 25-31.

417 Hauschke N, Wilde V. 1987. Paleolimulus fuchsbergensis n. sp. (Xiphosura, Merostomata) aus 418 der oberen Trias von Nordwestdeutschland, mit einer Übersicht zur Systematik und Verbreitung 419 rezenter Limuliden. Paläontologische Zeitschrift 61 (1/2): 87-108.

420 Hethke M, Fürsich FT, Jiang B, Klaus R. 2013. Oxygen deficiency in Lake Sihetun; formation 421 of the Lower Cretaceous Liaoning Fossillagerstätte (China). Journal of the Geological Society 422170 (5): 817-831.

423 Hofmann R, Hautmann M, Wasmer M, Bucher H. 2013. Palaeoecology of the Spathian 424 Virgin Formation (Utah, USA) and its implications for the Early Triassic recovery. Acta 425 Palaeontologica Polonica 58 (1): 149-173.

426 Hu S-x, Zhang Q-y, Chen Z-Q, Zhou C-y, Lü T, Xie T, Wen W, Huang J-y, Benton MJ.

427 2011. The Luoping biota: exceptional preservation, and new evidence on the Triassic recovery 428 from end-Permian mass extinction. Proceedings of the Royal Society B: Biological Sciences 278 429 (1716): 2274-2282. 
430

431

432

433

434

435

436

437

438

439

440

441

442

443

444

445

446

447

448

449

450

451

452

Hu S, Zhang Q, Feldmann RM, Benton MJ, Schweitzer CE, Huang J, Wen W, Zhou C, Xie

T, Lü T, Hong S. 2017. Exceptional appendage and soft-tissue preservation in a Middle Triassic horseshoe crab from SW China. Scientific Reports 7 (1): 14112.

Jablonski D. 2002. Survival without recovery after mass extinctions. Proceedings of the

National Academy of Sciences 99 (12): 8139-8144.

Kalandadze NN, Ochev VG, Tatarinov LP, Chudinov PK, Shishkin MA. 1968. Katalog permskikh i triasovykh tetrapod SSSR. Doklady Akademii Nauk SSSR 179: 72-91.

Lamsdell JC. 2020. The phylogeny and systematics of Xiphosura. PeerJ 8: e10431.

Lange W. 1923. Über neue Fossilfunde aus der Trias von Göttingen. Zeitschrift der deutschen geologischen Gesellschaft 74: 162-168.

Lerner AJ, Lucas SG, Lockley M. 2017. First fossil horseshoe crab (Xiphosurida) from the Triassic of North America. Neues Jahrbuch für Geologie und Paläontologie-Abhandlungen 286 (3): 289-302.

Luo M, Chen ZQ. 2014. New arthropod traces from the Lower Triassic Kockatea Shale formation, northern Perth Basin, Western Australia: ichnology, taphonomy and palaeoecology. Geological Journal 49 (2): 163-176.

Luo M, Shi GR, Buatois LA, Chen Z-Q. 2020. Trace fossils as proxy for biotic recovery after the end-Permian mass extinction: A critical review. Earth-Science Reviews 203: 103059.

Luo M, Shi GR, Hu S, Benton MJ, Chen Z-Q, Huang J, Zhang Q, Zhou C, Wen W. 2019. Early Middle Triassic trace fossils from the Luoping Biota, southwestern China: Evidence of recovery from mass extinction. Palaeogeography, Palaeoclimatology, Palaeoecology 515: 6-22.

Lustri L, Laibl L, Bicknell RDC. 2021. A revision of Prolimulus woodwardi Fritsch, 1899 with comparison to other paedomorphic belinurids. PeerJ 9: e10980. 
453 Meek FB. 1867. Notes on a new genus of fossil Crustacea. Geological Magazine, Decade 4:

$454 \quad 320-321$.

455 Meischner K-D. 1962. Neue Funde von Psammolimulus gottingensis (Merostomata, Xiphosura)

456 aus dem Mittleren Buntsandstein von Göttingen. Paläontologische Zeitschrift 36 (1): 185-193.

457 Minikh MG, Minikh AV. 1997. Ichthyofaunal correlation of the Triassic deposits from the

458 northern Cis-Caspian and southern Cis-Urals regions. Geodiversitas 19 (2): 279-292.

459 Novikov IV. 2018. Early Triassic amphibians of Eastern Europe: Evolution of dominant groups

460 and traits of changing communities (in Russian). Transactions of Paleontological Institute,

461 Russian Academy of Sciences 296: 1-358.

462 Ochev WG, Shishkin MA. 1989. On the principles of global correlation at the continental

463 Triassic on the tetrapods. Acta Palaeontologica Polonica 34 (2): 149-173.

464 Payne JL, Lehrmann DJ, Wei J, Orchard MJ, Schrag DP, Knoll AH. 2004. Large

465 perturbations of the carbon cycle during recovery from the end-Permian extinction. Science $\mathbf{3 0 5}$ 466 (5683): 506-509.

467 Pickett JW. 1984. A new freshwater limuloid from the middle Triassic of New South Wales.

468 Palaeontology 27 (3): 609-621.

469 Pictet F-J. 1846. Traité Élémentaire De Paléontologie Ou Histoire Naturelle Des Animaux

470 Fossiles: Baillière.

471 Ponomarenko AG. 1985. King crabs and eurypterids from the Permian and Mesozoic of the

472 USSR. Paleontological Journal 19: 100-104.

473 Ponomarenko AG. 2016. Insects during the time around the Permian-Triassic crisis.

$474 \quad$ Paleontological Journal 50 (2): 174-186. 
475 Riek EF. 1955. A new xiphosuran from the Triassic sediments at Brookvale, New South Wales.

476 Records of the Australian Museum 23 (5): 281-282.

477 Riek EF. 1968. Re-examination of two arthropod species from the Triassic of Brookvale, New

478 South Wales. Records of the Australian Museum 27 (17): 313-321.

479 Rodland DL, Bottjer DJ. 2001. Biotic recovery from the end-Permian mass extinction:

480 behavior of the inarticulate brachiopod Lingula as a disaster taxon. Palaios 16 (1): 95-101.

481 Romero PA, Vía Boada L. 1977. Tarracolimulus rieki nov. gen., nov. sp., nuevo Limulido del

482 Triasico de Montral-Alcover (Tarragona). Cuadernos Geologia Ibérica 4: 239-246.

483 Schimper W-P. 1853. Palaeontologica alsatica: ou fragments paléontologiques des différents

484 terrains stratifiés qui se rencontrent en Alsace. Mémoires de la Société du Muséum d'Histoire

485 Naturelle de Strasbourg 4: 1-10.

486 Schram FR. 1979. Limulines of the Mississippian Bear Gulch Limestone of Central Montana,

487 USA. Transactions of the San Diego Society of Natural History 19 (6): 67-74.

488 Schubert JK, Bottjer DJ. 1992. Early Triassic stromatolites as post-mass extinction disaster

489 forms. Geology 20 (10): 883-886.

490

491

492

493

494

495

Shcherbakov DE. 2008a. Insect recovery after the Permian/Triassic crisis. Alavesia 2: 125-131.

Shcherbakov DE. 2008b. On Permian and Triassic insect faunas in relation to biogeography and the Permian-Triassic crisis. Paleontological Journal 42 (1): 15-31.

Shcherbakov DE, Timm T, Tzetlin AB, Vinn O, Zhuravlev AY. 2020. A probable

oligochaete from an Early Triassic Lagerstätte of the southern Cis-Urals and its evolutionary implications. Acta Palaeontologica Polonica 65 (2): 219-233. 
496

497

498

499

500

501

502

503

504

505

506

507

508

509

510

511

512

513

514

515

516

517 518 Geologicheskoe Upravlenie, 109-148.

Shcherbakov DE, Vinn O, Zhuravlev AY. 2021. Disaster microconchids from the uppermost

Permian and Lower Triassic lacustrine strata of the Cis-Urals and the Tunguska and Kuznetsk basins (Russia). Geological Magazine: 1-23, in press.

Shi G, Woods AD, Yu M-Y, Li X-W, Wei H-Y, Qiao D. 2019. Lower Triassic limulid trackways (Kouphichnium) from the southwestern margin of the Yangtze carbonate platform: paleoenvironmental and paleoecological implications. Palaios 34 (4): 229-243.

Shishkin MA, Novikov IV. 2017. Early stages of recovery of the East European tetrapod fauna after the end-Permian crisis. Paleontological Journal 51 (6): 612-622.

Shishkin MA, Ochev VG, Tverdokhlebov VP, Vergay IF, Gomankov AV, Kalandadze NN, Leonova EM, Lopato AY, Makarova IS, Minikh MG, Molostovskiy EM, Novikov IV, Sennikov AG. 1995. Biostratigrafiya kontinental'nogo triasa yuzhnogo Predural'ya (Biostratigraphy of the Continental Triassic in the Southern Cis-Urals) (in Russian). Moscow: Nauka.

Størmer L. 1952. Phylogeny and taxonomy of fossil horseshoe crabs. Journal of Paleontology 26 (4): 630-640.

Tintori A, Hitij T, Jiang D, Lombardo C, Sun Z. 2014. Triassic actinopterygian fishes: the recovery after the end-Permian crisis. Integrative Zoology 9 (4): 394-411.

Tverdokhlebov VP. 1967. Petropavlovka, Berezovy. In: Morozov NS, ed. Putevoditel' ekskursii po verhnepermskim i triasovym kontinental'nym obrazovaniyam yugo-vostoka Russkoy platformy i Priural'ya (Guidebook of the Excursion on Upper Permian and Triassic Continental Formations of the South-East of the Russian Platform and the Cis-Urals) (In Russian). Saratov:

17 Saratovskiy Gosudarstvennyy Universitet imeni N. G. Chernyshevskogo, Orenburgskoe 
519 Tverdokhlebov VP. 1987. Triasovye ozera Yuzhnogo Priural'ya (Triassic lakes of the southern

520 Cis-Urals. In: Martinson GG, and Neustrueva IY, eds. Istoriya ozer pozdnego paleozoya $i$

521 rannego mezozoya (Late Palaeozoic and Early Mesozoic Lake History) (In Russian) Leningrad:

522 Nauka, 235-242.

523 Tverdokhlebov VP, Tverdokhlebova GI, Surkov MV, Benton MJ. 2003. Tetrapod localities

524 from the Triassic of the SE of European Russia. Earth-Science Reviews 60 (1-2): 1-66.

525 Twitchett RJ, Krystyn L, Baud A, Wheeley JR, Richoz S. 2004. Rapid marine recovery after

526 the end-Permian mass-extinction event in the absence of marine anoxia. Geology 32 (9): 805-

527808.

528 Vía Boada L. 1987. Artropodos fosiles Triasicos de Alcover-Montral. II. Limulidos. Cuadernos

529 Geología Ibérica 11: 281-294.

530 Vía L, De Villalta JF. 1966. Hetrolimulus gadeai, nov. gen., nov. sp., représentant d'une

531 nouvelle famille de Limulacés dans le Trias d'Espagne. Comtes Rendues Sommaire Séances

532 Societé Géologique France 8: 57-59.

533 von Fritsch KWG. 1906. Beitrag zur Kenntnis der Tierwelt der deutschen Trias. Abhandlungen

534 der naturforschender Gesellschaft Halle 24: 220-285.

535 Vorobyeva EI, Minikh MG. 1968. Experimental application of biometry to the study of

536 ceratodontid dental plates (In Russian). Paleontological Journal 2: 76-87.

537 Xing Z-F, Lin J, Fu Y-X, Zheng W, Liu Y-L, Qi Y-A. 2021. Trace fossils from the Lower

538 Triassic of North China - a potential signature of the gradual recovery of a terrestrial ecosystem.

539 Palaeoworld 30: 95-105.

540 Zhang QY, Hu SX, Zhou CY, Lü T, Bai JK. 2009. First occurrence of horseshoe crab

541 (Arthropoda) fossils from China. Progress in Natural Science 19: 1090-1093. 
542 Zheng D, Chang S-C, Wang H, Fang Y, Wang J, Feng C, Xie G, Jarzembowski EA, Zhang

543 H, Wang B. 2018. Middle-Late Triassic insect radiation revealed by diverse fossils and isotopic 544 ages from China. Science Advances 4 (9): eaat1380.

545 Żyła D, Wegierek P, Owocki K, Niedźwiedzki G. 2013. Insects and crustaceans from the latest

546 Early-early Middle Triassic of Poland. Palaeogeography, Palaeoclimatology, Palaeoecology

547 371: 136-144.

548 
550 Figure 1: Geographical and geological information for the studied fossil site. (A) Map

551 showing locality of Petropavlovka III (red star). Dotted line represents boundaries of tectonic 552 regions, modified from Shcherbakov et al. (2021). (B) Stratigraphic log of Petropavlovka II-

553 IV sections showing location of horseshoe crab-bearing lens (modified from Tverdokhlebov, 554 1967).

555 Figure 2: Depiction of geometric morphometric data gathered here: four landmarks and one 556 semilandmark outline. Consider Supplementary Table 1 for description of landmarks.

557 Figure 3: Holotype of Attenborolimulus superspinosus gen. et sp. nov. PIN 5640/220, 558 counterpart. (A, B): Photograph and interpretative drawing. Abbreviations: Car: cardiac lobe;

559 Eye: lateral compound eye; Fla: thoracetronic flange; Fs: fixed spine; Med: medial thoracetronic 560 lobe; Oph: ophthalmic ridge; Pa: prosomal appendage; Pro: prosoma; Thr: thoracetron; Tel: 561 telson. Image credit: Sergey Bagirov.

562 Figure 4: Holotype of Attenborolimulus superspinosus gen. et sp. nov., PIN 5640/220, part. (A, 563 B): Photograph and interpretative drawing. Abbreviations: Car: cardiac lobe; Fla: thoracetronic 564 flange; Med: medial thoracetronic lobe; Oph: ophthalmic ridge; Pa: prosomal appendage; Pro: 565 prosoma; Thr: thoracetron; Tel: telson. Image credit: Dmitry Shcherbakov.

566 Figure 5: SEM images of the Attenborolimulus superspinosus gen. et sp. nov. (A, C, D):

567 Holotype, PIN 5640/220, counterpart. (A) Entire specimen. (C) Close up of box in (A), showing 568 small moveable spine notches and fixed spines (white arrows). (D): Close up of box in (A), 569 showing tubercles along prosomal thoracetronic border (white arrows). (B): Paratype, PIN 570 5640/200, part. Image credit: Dmitry Shcherbakov. 
571 Figure 6: Paratype PIN 5640/200 of Attenborolimulus superspinosus gen. et sp. nov. showing

572 key prosomal features. (A, B): Part, photograph and interpretative drawing. (C, D): Counterpart,

573 photograph and interpretative drawing. Abbreviation: Car: cardiac lobe. Image credit: (A) Sergey

574 Bagirov; (C) Dmitry Shcherbakov.

575 Figure 7: Paratype PIN 5640/217 of Attenborolimulus superspinosus gen. et sp. nov. (A, B):

576 Photograph and interpretative drawing. Image credit: Sergey Bagirov.

577 Figure 8. Reconstruction of Attenborolimulus superspinosus gen. et sp. nov. Reconstruction 578 credited to Katrina Kenny.

579 Figure 9. Three examined xiphosurid families in PC space. Austrolimulids occupy most positive 580 PC1 space while limulids and paleolimulids are mostly constrained to negative PC1 space.

581 Attenborolimulus superspinosus gen. et sp. nov. falls within the convex hull occupied by

582 Austrolimulidae. Note that the austrolimulid morphospace excludes Limulitella specimens, as the 583 position of this genus in Austrolimulidae is considered dubious.

584 Figure 10. PC plot showing morphospace occupied by xiphosurid genera. Where more than one 585 specimen was digitised, genera are bound by convex hulls. Attenborolimulus superspinosus gen. 586 et sp. nov. is not bound by any convex hull, excluding the specimen from other genera.

587 Supplementary Information 1: TPS file of analysed specimens.

588 Supplementary Information 2: CSV file used for semilandmark sliding.

589 Supplementary Information 3: CSV file of PCA results. Includes family, generic and temporal 590 da 
Figure 1

Figure 1: Geographical and geological information for the studied fossil site.

(A) Map showing locality of Petropavlovka III (red star). Dotted line represents boundaries of tectonic regions, modified from Shcherbakov et al. (2021). (B) Stratigraphic log of

Petropavlovka II-IV sections showing location of horseshoe crab-bearing lens (modified from Tverdokhlebov, 1967).
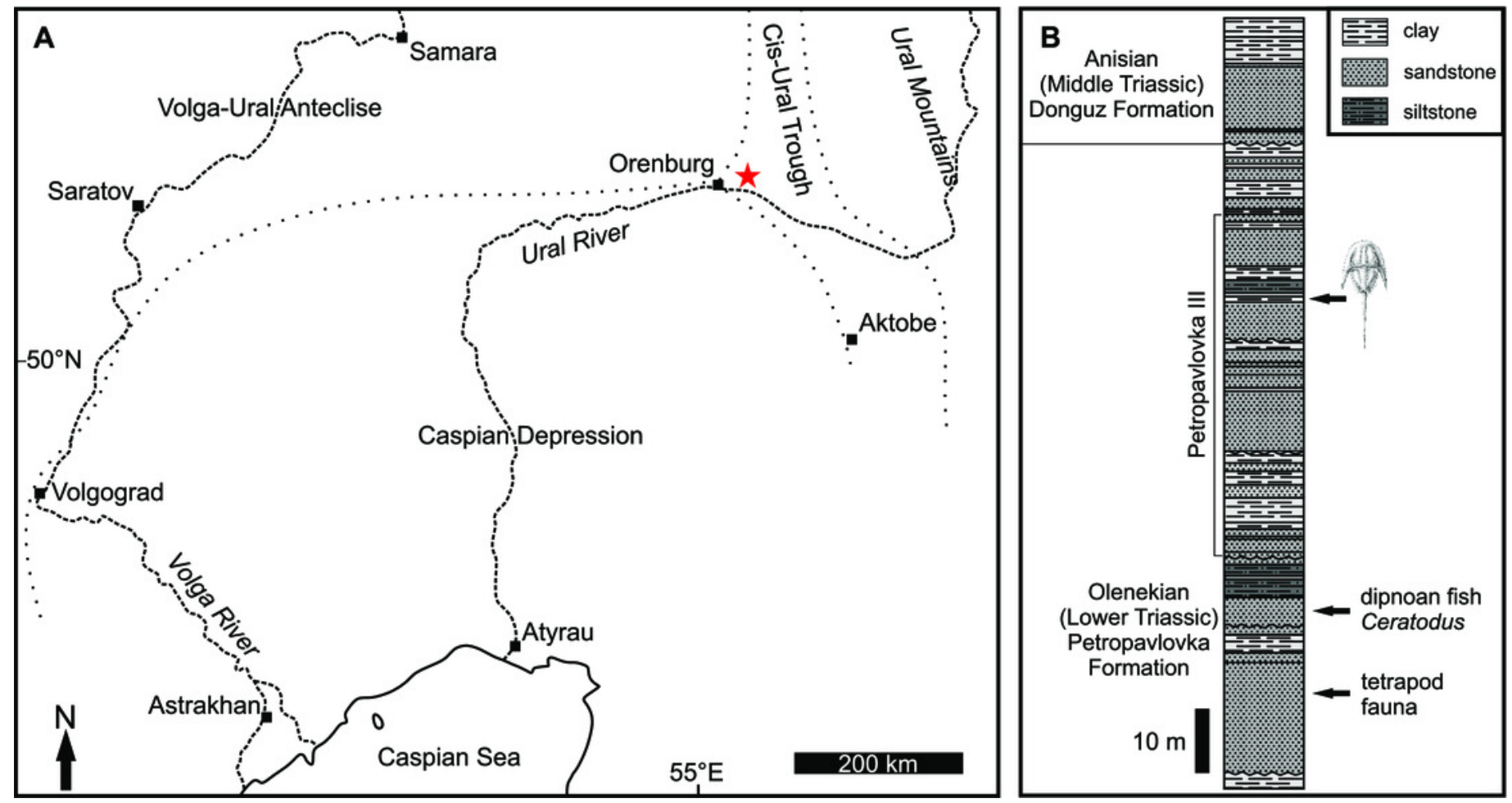
Figure 2

Figure 2: Depiction of geometric morphometric data gathered here: four landmarks and one semilandmark outline.

Consider Supplementary Table 1 for description of landmarks. 


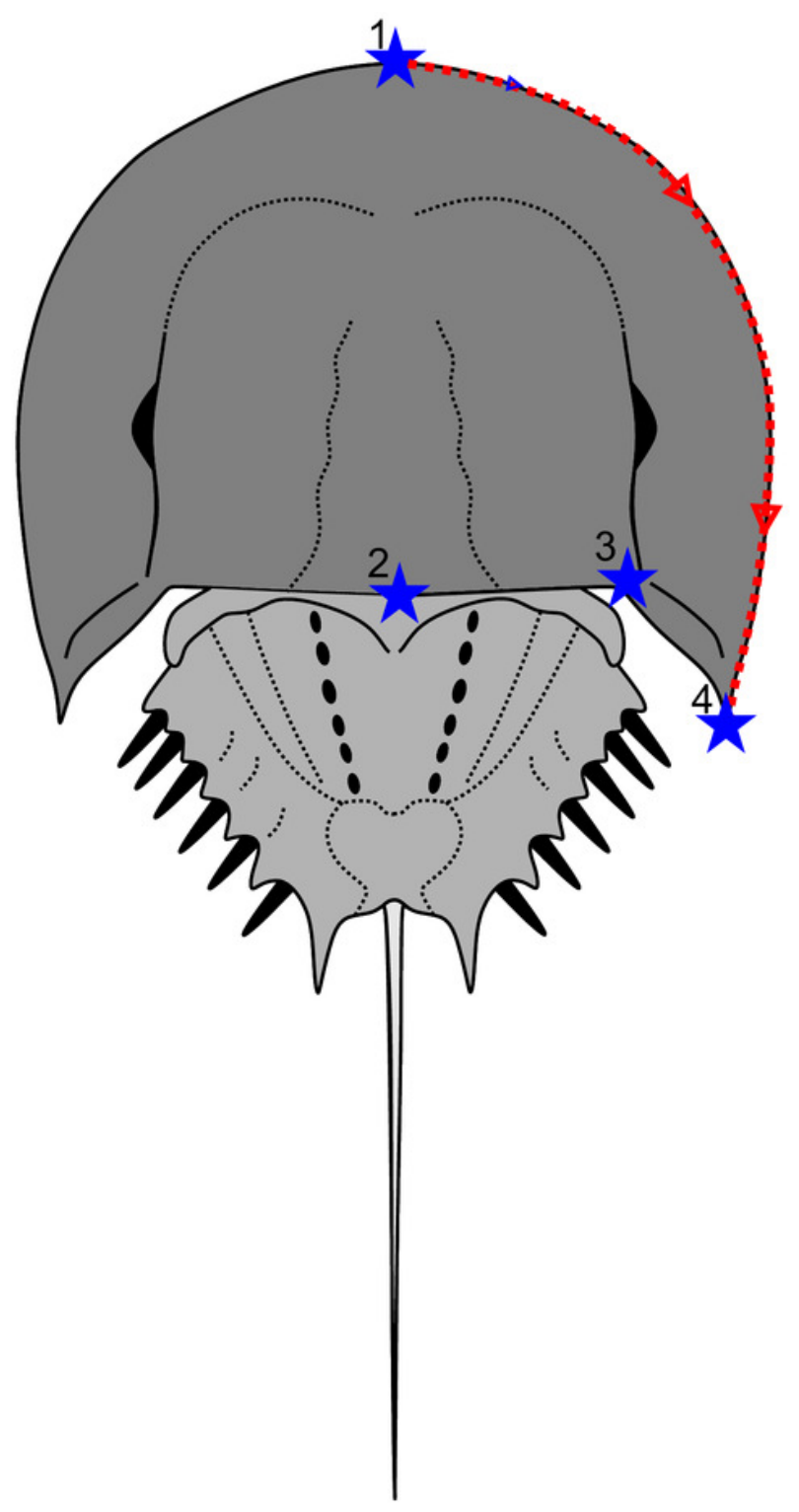




\section{Figure 3}

Figure 3: Holotype of Attenborolimulus superspinosus gen. et sp. nov. PIN 5640/220, counterpart.

(A, B): Photograph and interpretative drawing. Abbreviations: Car: cardiac lobe; Eye: lateral compound eye; Fla: thoracetronic flange; Fs: fixed spine; Med: medial thoracetronic lobe; Oph: ophthalmic ridge; Pa: prosomal appendage; Pro: prosoma; Thr: thoracetron; Tel: telson. Image credit: Sergey Bagirov . 

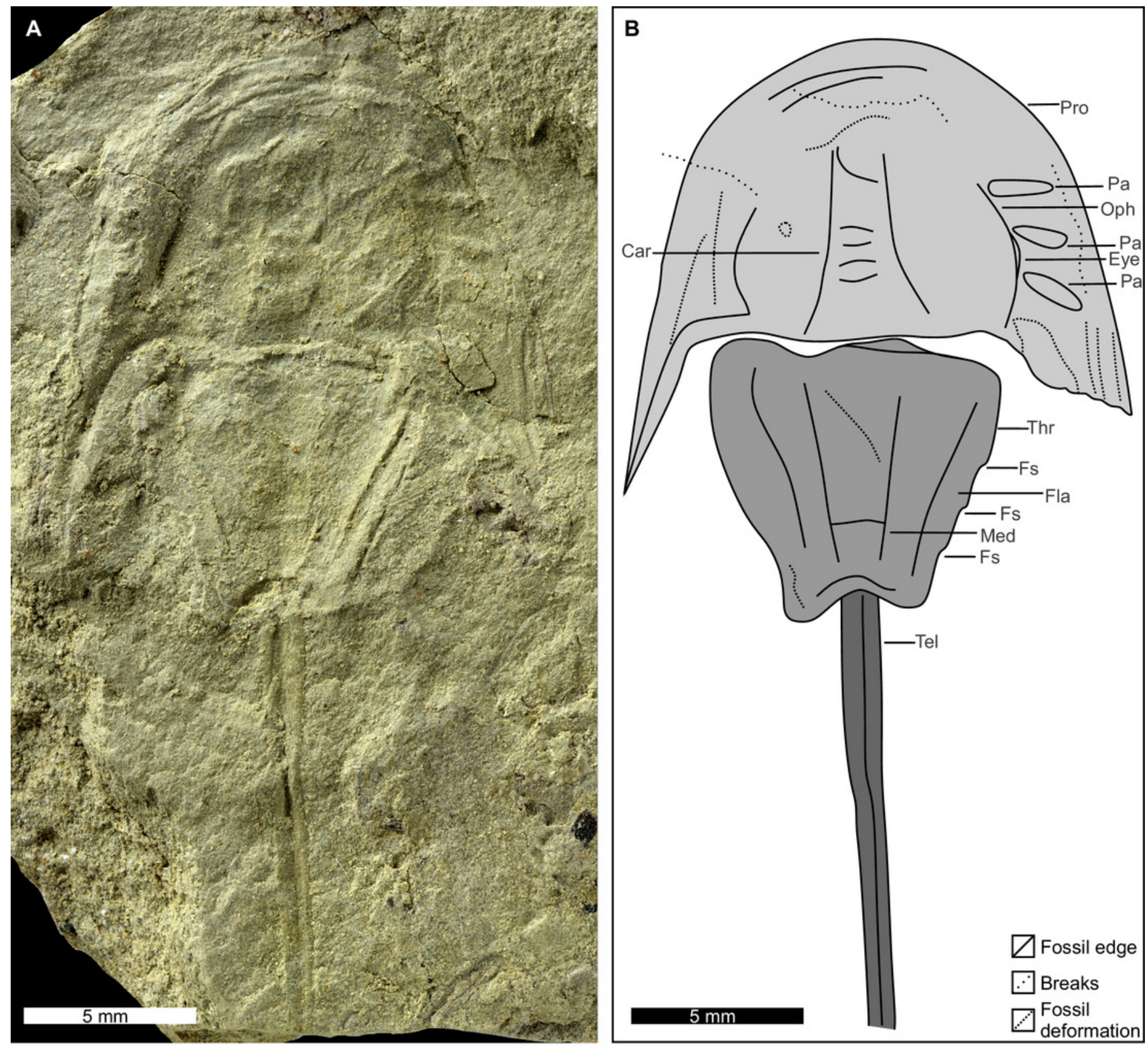


\section{Figure 4}

Figure 4: Holotype of Attenborolimulus superspinosus gen. et sp. nov., PIN 5640/220, part.

(A, B): Photograph and interpretative drawing. Abbreviations: Car: cardiac lobe; Fla:

thoracetronic flange; Med: medial thoracetronic lobe; Oph: ophthalmic ridge; Pa: prosomal appendage; Pro: prosoma; Thr: thoracetron; Tel: telson. Image credit: Dmitry Shcherbakov. 

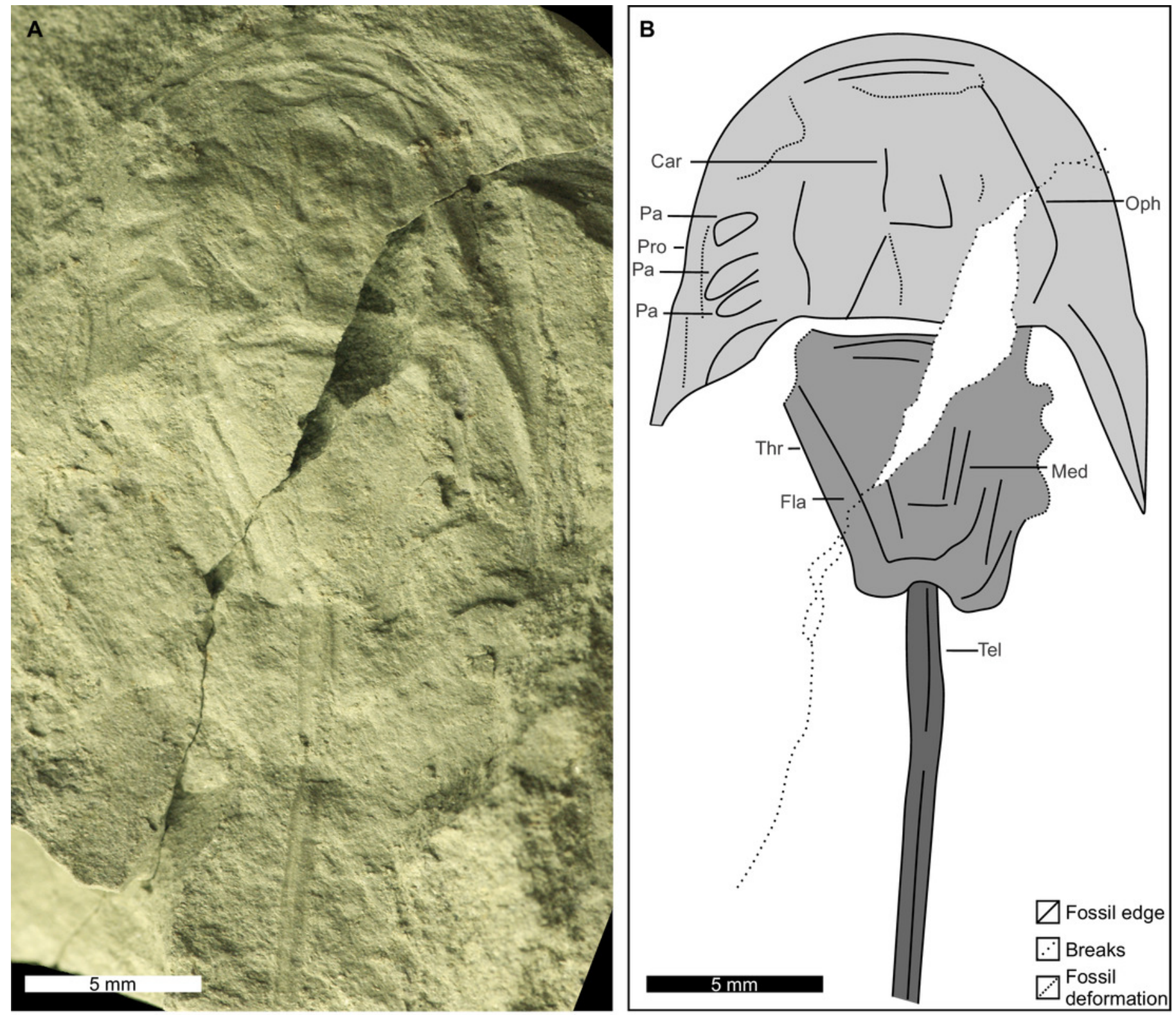


\section{Figure 5}

Figure 5: SEM images of the Attenborolimulus superspinosus gen. et sp. nov. (A, C, D): Holotype, PIN 5640/220, counterpart.

(A) Entire specimen. (C) Close up of box in (A), showing small moveable spine notches and fixed spines (white arrows). (D): Close up of box in (A), showing tubercles along prosomal thoracetronic border (white arrows). (B): Paratype, PIN 5640/200, part. Image credit: Dmitry Shcherbakov. 

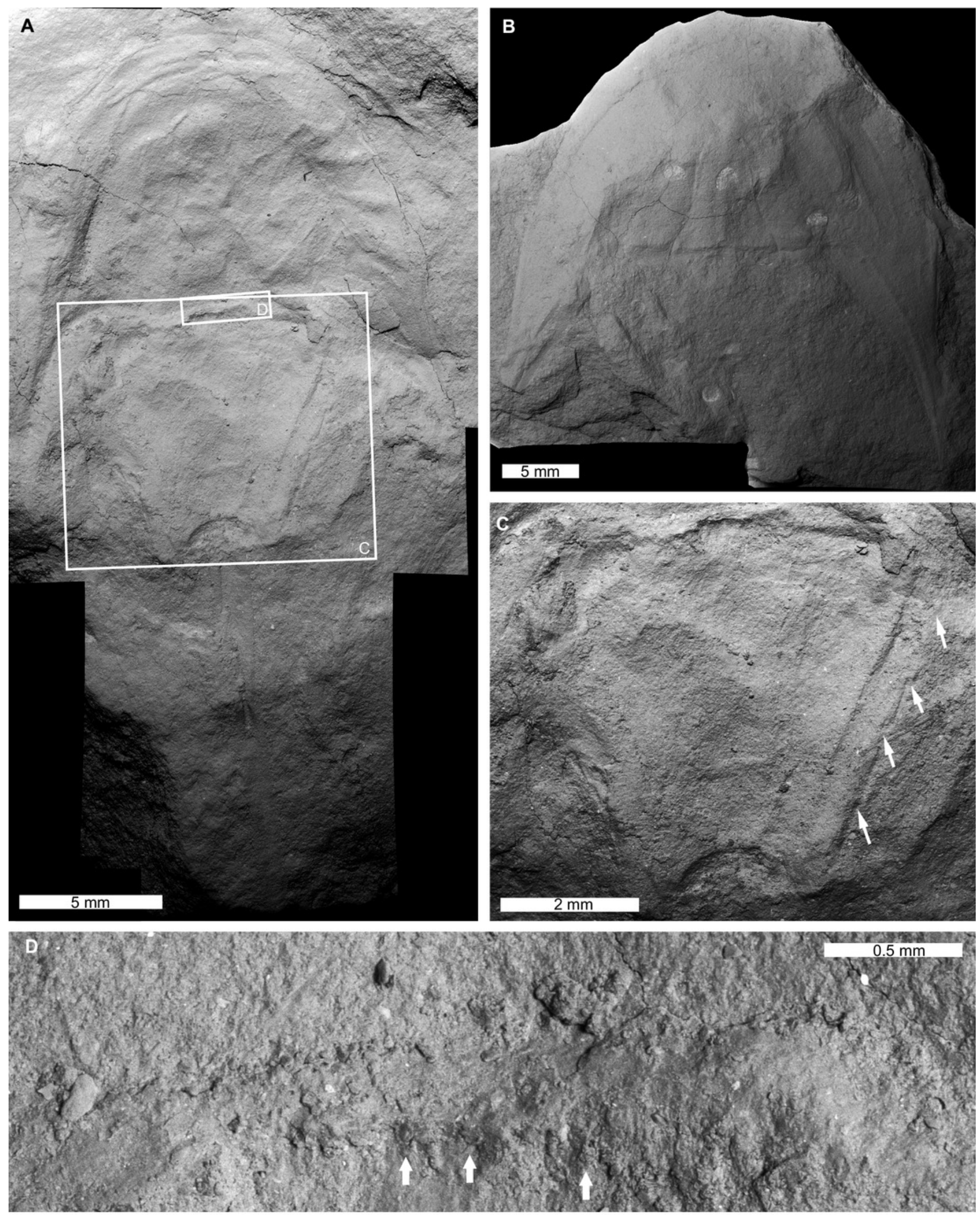


\section{Figure 6}

Figure 6: Paratype PIN 5640/200 of Attenborolimulus superspinosus gen. et sp. nov. showing key prosomal features.

(A, B): Part, photograph and interpretative drawing. (C, D): Counterpart, photograph and interpretative drawing. Abbreviation: Car: cardiac lobe. Image credit: (A) Sergey Bagirov; (C) Dmitry Shcherbakov. 

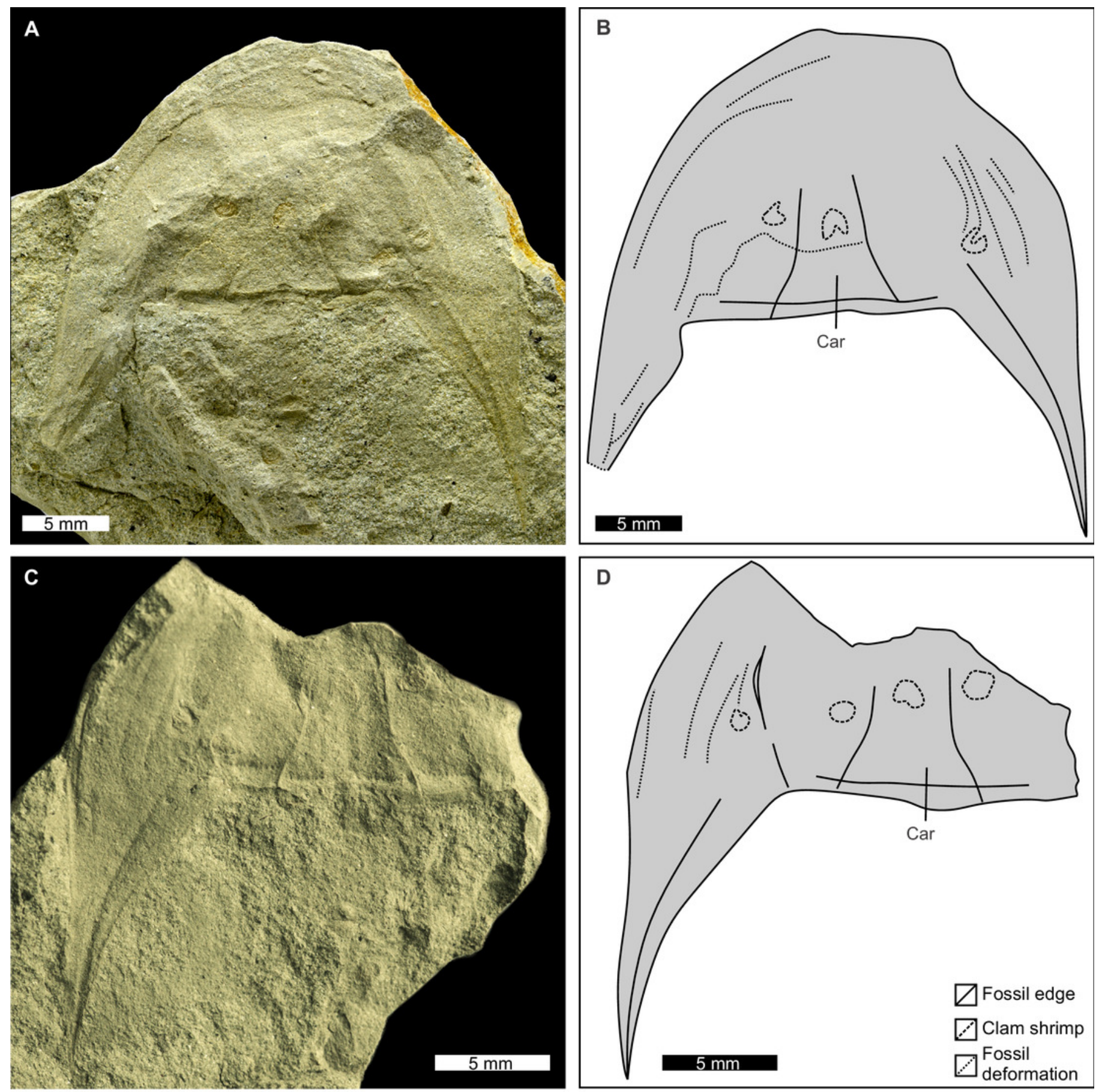
Figure 7

Figure 7: Paratype PIN 5640/217 of Attenborolimulus superspinosus gen. et sp. nov. (A, B): Photograph and interpretative drawing. Image credit: Sergey Bagirov. 

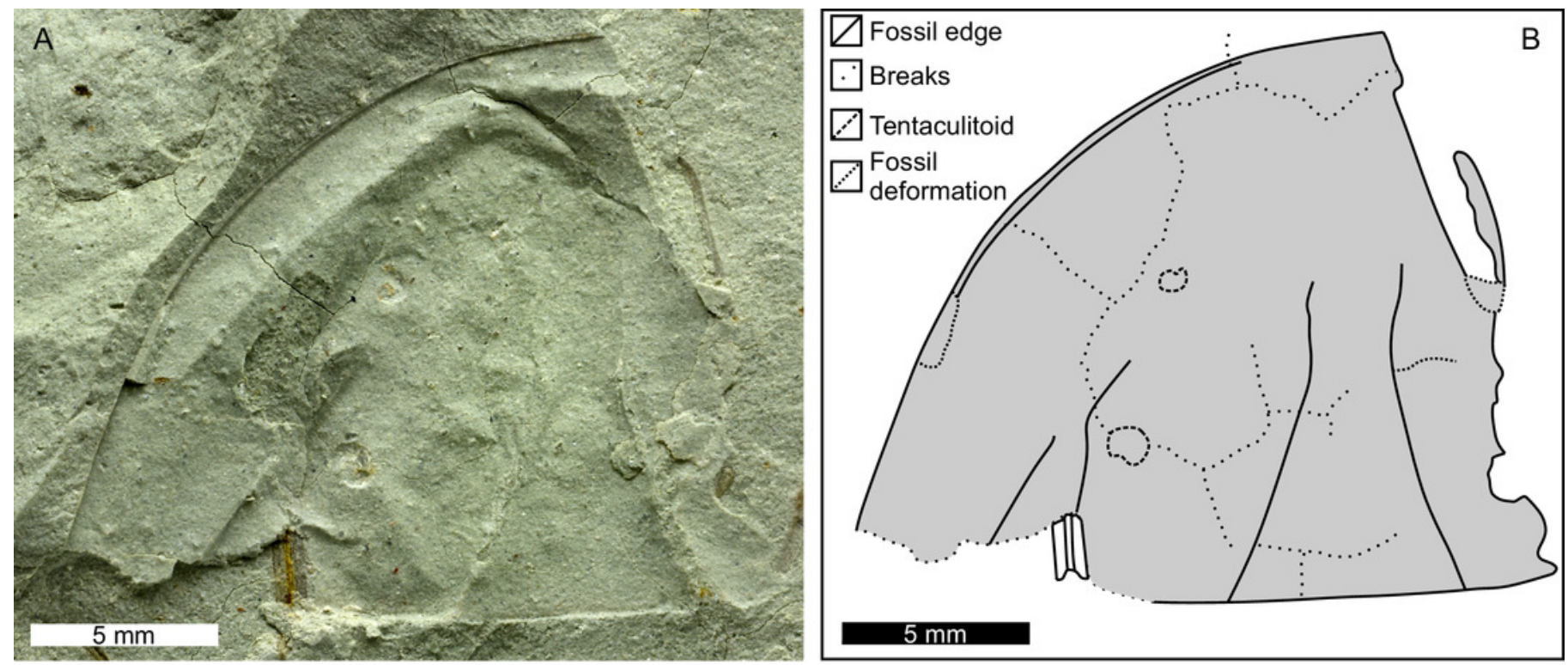
Figure 8

Figure 8. Reconstruction of Attenborolimulus superspinosus gen. et sp. nov.

Reconstruction credited to Katrina Kenny. 


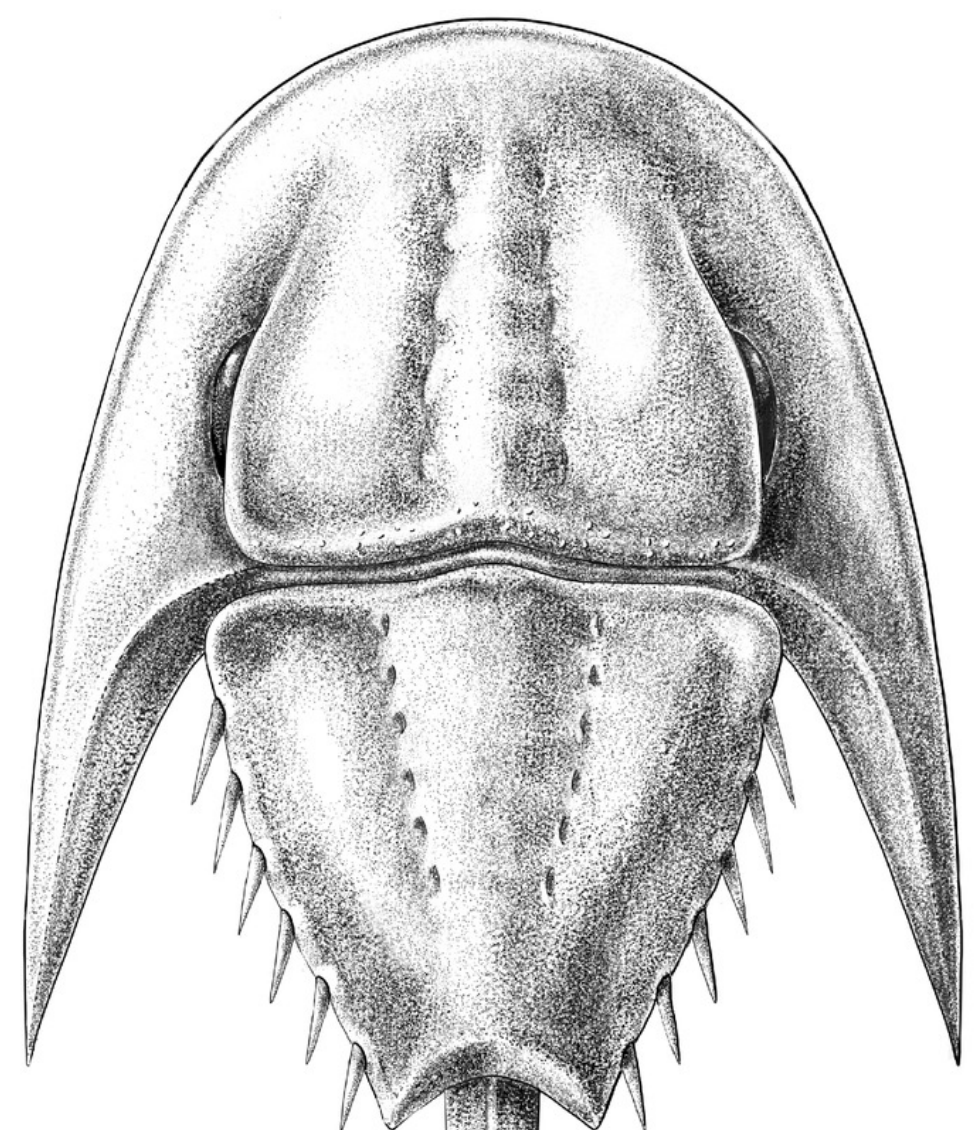

(C) Katrina Kenny 2021 


\section{Figure 9}

Figure 9. Three examined xiphosurid families in PC space.

Austrolimulids occupy most positive PC1 space while limulids and paleolimulids are mostly constrained to negative PC1 space. Attenborolimulus superspinosus gen. et sp. nov. falls within the convex hull occupied by Austrolimulidae. Note that the austrolimulid morphospace excludes Limulitella specimens, as the position of this genus in Austrolimulidae is considered dubious. 


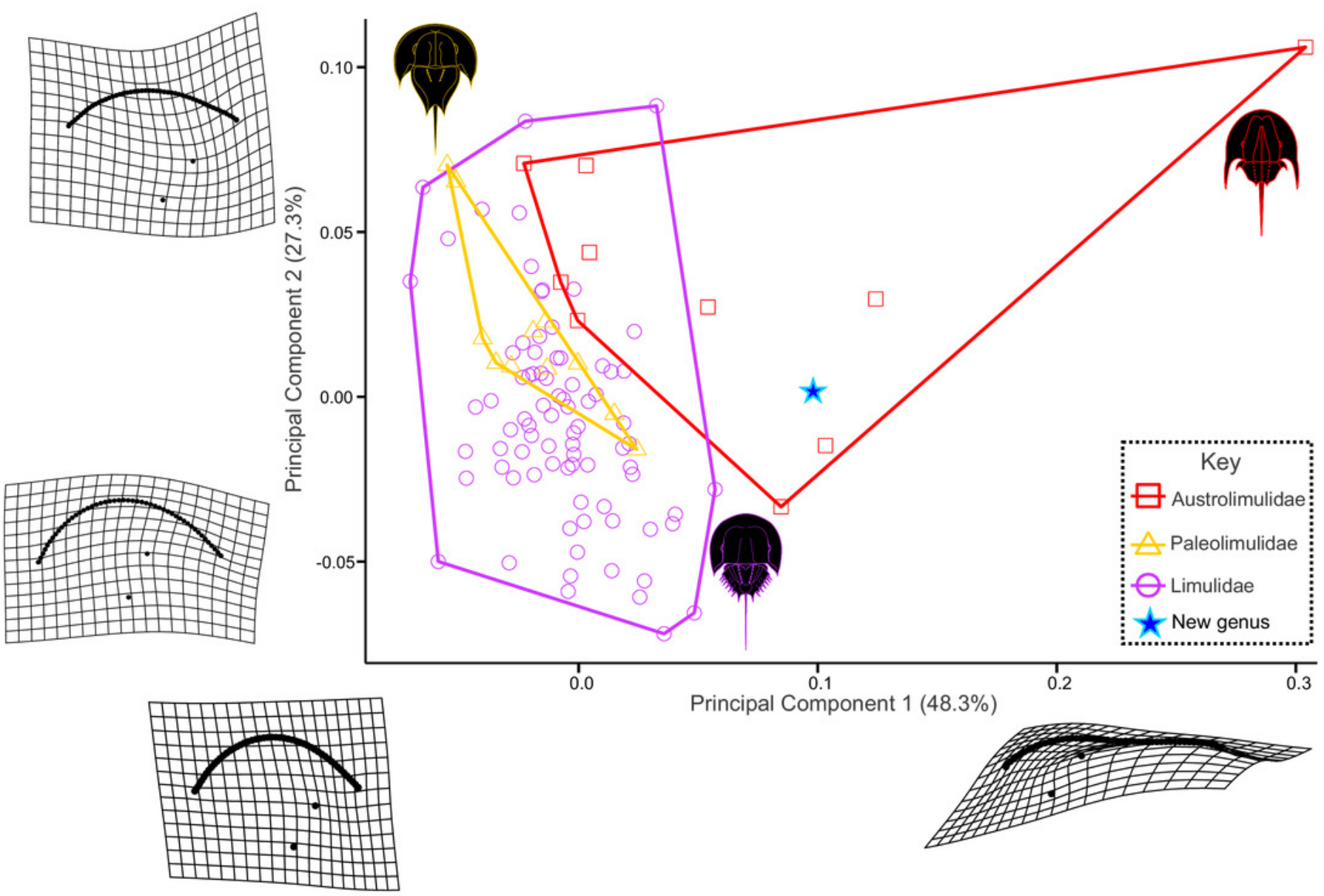




\section{Figure 10}

Figure 10. PC plot showing morphospace occupied by xiphosurid genera.

Where more than one specimen was digitised, genera are bound by convex hulls.

Attenborolimulus superspinosus gen. et sp. nov. is not bound by any convex hull, excluding the specimen from other genera. 


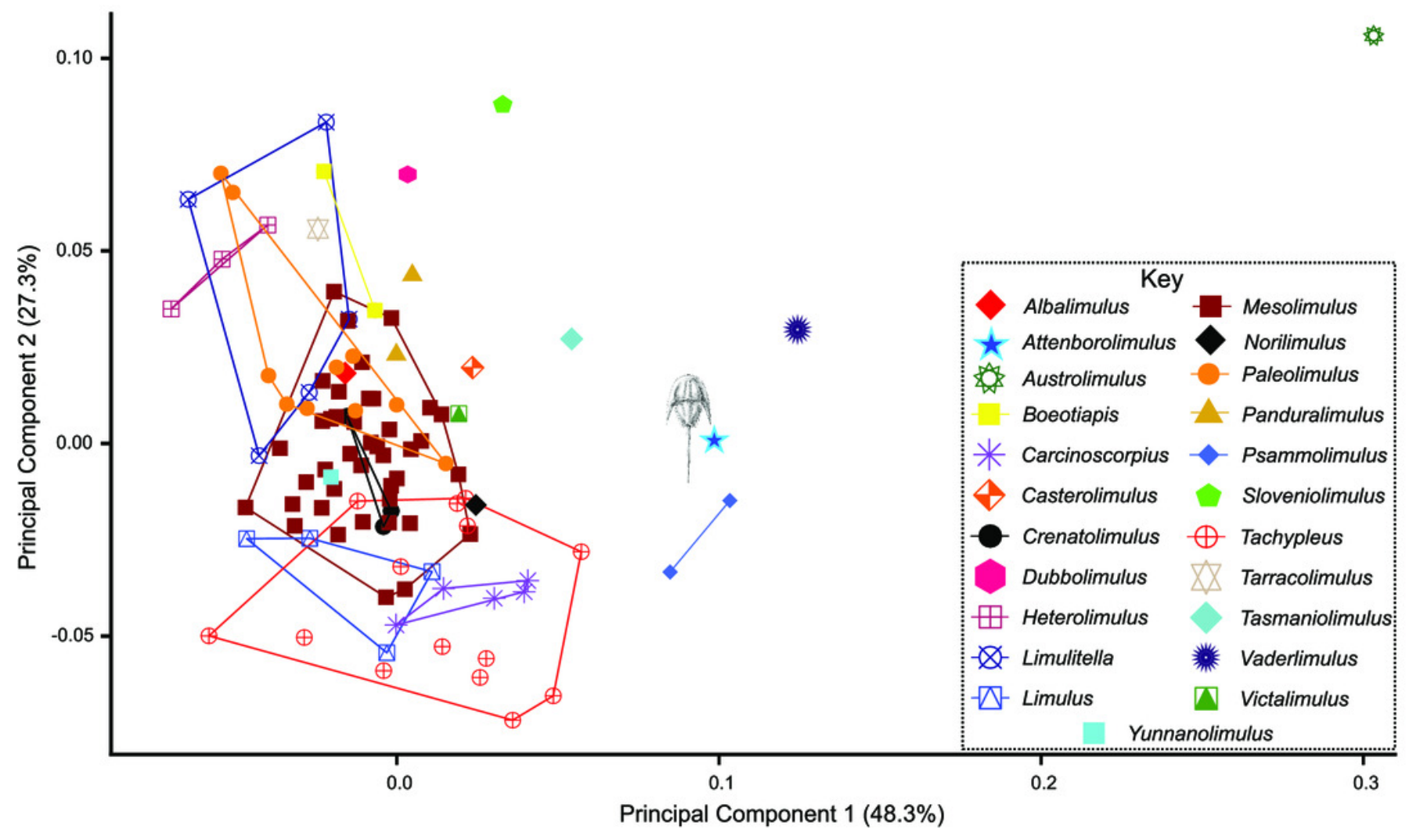




\section{Table $\mathbf{1}$ (on next page)}

Table 1: Summary of known Triassic xiphosurids.

Taxa are order by family and then alphabetically by genus and species. Temporal data taken from Bicknell \& Pates (2020) and Bicknell et al. (2020, 2021a, b). Note the uncertain placement of Limulitella in Austrolimulidae, and Yunnanolimulus henkeli. In Figure 10 and Supplemental Information 3, Limulitella is placed within Limulidae, and Yunnanolimulus (?) henkeli is referred to Limulitella henkeli (following Bicknell et al., 2021a). 


\begin{tabular}{|c|c|c|c|c|}
\hline Taxon & Family & Formation, locality & Age & $\begin{array}{l}\text { Depositional } \\
\text { environment }\end{array}$ \\
\hline Austrolimulus fletcheri Riek, 1955 & $\begin{array}{l}\text { Austrolimulida } \\
\text { e }\end{array}$ & $\begin{array}{l}\text { Hawkesbury Sandstone, New } \\
\text { South Wales, Australia }\end{array}$ & $\begin{array}{l}\text { Middle Triassic (Anisian, } \\
247.2-242 \mathrm{Ma} \text { ) }\end{array}$ & $\begin{array}{l}\text { Marginal marine to } \\
\text { freshwater }\end{array}$ \\
\hline $\begin{array}{l}\text { Attenborolimulus superspinosus gen. et } \\
\text { sp. nov. }\end{array}$ & $\begin{array}{l}\text { Austrolimulida } \\
\mathrm{e}\end{array}$ & $\begin{array}{l}\text { Petropavlovka Formation, Cis- } \\
\text { Urals, Russia }\end{array}$ & $\begin{array}{l}\text { Early Triassic (Olenekian, } \\
251.2-247.2 \mathrm{Ma})\end{array}$ & $\begin{array}{l}\text { Marginal marine to } \\
\text { freshwater }\end{array}$ \\
\hline $\begin{array}{l}\text { Batracholimulus fuchsbergensis } \\
\text { (Hauschke \& Wilde, 1987) }\end{array}$ & $\begin{array}{l}\text { Austrolimulida } \\
\text { e }\end{array}$ & Exter Formation, Germany & $\begin{array}{l}\text { Late Triassic (Rhaetian, 208.5- } \\
201.3 \mathrm{Ma} \text { ) }\end{array}$ & $\begin{array}{l}\text { Marginal marine to } \\
\text { freshwater }\end{array}$ \\
\hline Dubbolimulus peetae Pickett, 1984 & $\begin{array}{l}\text { Austrolimulida } \\
\text { e }\end{array}$ & $\begin{array}{l}\text { Ballimore Formation, New South } \\
\text { Wales, Australia }\end{array}$ & Middle Triassic (Ladinian) & $\begin{array}{l}\text { Marginal marine to } \\
\text { freshwater }\end{array}$ \\
\hline Limulitella bronni (Schimper, 1853) & $\begin{array}{l}\text { ?Austrolimulid } \\
\text { ae }\end{array}$ & Grés á Voltzia Formation, France & $\begin{array}{l}\text { Middle Triassic (Anisian, } \\
247.2-242 \mathrm{Ma})\end{array}$ & $\begin{array}{l}\text { Marginal marine to } \\
\text { freshwater }\end{array}$ \\
\hline $\begin{array}{l}\text { Limulitella liasokeuperinus (Braun, } \\
1860 \text { ) }\end{array}$ & $\begin{array}{l}\text { ?Austrolimulid } \\
\text { ae }\end{array}$ & $\begin{array}{l}\text { ?Exter Formation-?Bayreuth } \\
\text { Formation, Germany }\end{array}$ & $\begin{array}{l}\text { Late Triassic-Early Jurassic } \\
\text { (?Rhaetian- Hettangian, 208.6- } \\
\text { 199.3 Ma) }\end{array}$ & $\begin{array}{l}\text { Marginal marine to } \\
\text { freshwater }\end{array}$ \\
\hline $\begin{array}{l}\text { Limulitella tejraensis } \text { Błażejowski, } \\
\text { Niedźwiedzki, Boukhalfa \& Soussi, } 2017\end{array}$ & $\begin{array}{l}\text { ?Austrolimulid } \\
\text { ae }\end{array}$ & Ouled Chebbi Formation, Tunisia & $\begin{array}{l}\text { Middle Triassic (Anisian-Early } \\
\text { Ladinian, 247.2-237 Ma) }\end{array}$ & $\begin{array}{l}\text { Marginal marine to } \\
\text { freshwater }\end{array}$ \\
\hline $\begin{array}{l}\text { Limulitella volgensis Ponomarenko, } \\
1985\end{array}$ & $\begin{array}{l}\text { ?Austrolimulid } \\
\text { ae }\end{array}$ & Rybinsk Formation, Russia & $\begin{array}{l}\text { Early Triassic (Olenekian, } \\
251.2-247.2 \mathrm{Ma})\end{array}$ & Marine \\
\hline $\begin{array}{l}\text { Psammolimulus gottingensis Lange, } \\
1923\end{array}$ & $\begin{array}{l}\text { Austrolimulida } \\
\text { e }\end{array}$ & Solling Formation, Germany & $\begin{array}{l}\text { Early Triassic (Olenekian, } \\
\text { Spathian, 251.2-247.2 Ma) }\end{array}$ & $\begin{array}{l}\text { Marginal marine to } \\
\text { freshwater }\end{array}$ \\
\hline $\begin{array}{l}\text { Vaderlimulus tricki Lerner, Lucas \& } \\
\text { Lockley, } 2017\end{array}$ & $\begin{array}{l}\text { Austrolimulida } \\
\text { e }\end{array}$ & Thaynes Group, Idaho, USA & $\begin{array}{l}\text { Early Triassic (Olenekian, } \\
\text { Spathian) }\end{array}$ & Marginal marine \\
\hline $\begin{array}{l}\text { Heterolimulus gadeai (Vía \& Villalta, } \\
\text { 1966) }\end{array}$ & Limulidae & $\begin{array}{l}\text { Alcover Limestone Formation, } \\
\text { Spain }\end{array}$ & Middle Triassic (Ladinian) & Marine \\
\hline Keuperlimulis vicensis (Bleicher, 1897) & Limulidae & $\begin{array}{l}\text { Marnes Irisées Supérieures } \\
\text { Formation, France }\end{array}$ & Late Triassic & Marine \\
\hline Mesolimulus crespelli Vía Boada, 1987 & Limulidae & $\begin{array}{l}\text { Alcover Limestone Formation, } \\
\text { Spain }\end{array}$ & Middle Triassic (Ladinian) & Marine \\
\hline $\begin{array}{l}\text { Sloveniolimulus rudkini Bicknell, } \\
\text { Žalohar, Miklavc, Celarc, Križnar \& } \\
\text { Hitij, } 2019\end{array}$ & Limulidae & Strelovec Formation, Slovenia & Middle Triassic (Anisian) & Marine \\
\hline $\begin{array}{l}\text { Tarracolimulus rieki Romero \& Vía } \\
\text { Boada, } 1977\end{array}$ & Limulidae & $\begin{array}{l}\text { Alcover Limestone Formation, } \\
\text { Spain }\end{array}$ & Middle Triassic (Ladinian) & Marine \\
\hline $\begin{array}{l}\text { Yunnanolimulus (?) henkeli (von Fritsch, } \\
\text { 1906) }\end{array}$ & Limulidae & Jena Formation, Germany & Middle Triassic (Anisian) & Marine \\
\hline $\begin{array}{l}\text { Yunnanolimulus luopingensis Zhang, Hu, } \\
\text { Zhou, Iv \& Bai, } 2009\end{array}$ & Limulidae & $\begin{array}{l}\text { Guanling Formation, Luoping, } \\
\text { China }\end{array}$ & Middle Triassic (Anisian) & Marine \\
\hline
\end{tabular}


2 Table 1: Summary of known Triassic xiphosurids. Taxa are order by family and then alphabetically by genus and species. Temporal 3 data taken from Bicknell \& Pates (2020) and Bicknell et al. (2020, 2021a, b). Note the uncertain placement of Limulitella in

4 Austrolimulidae, and Yunnanolimulus henkeli. In Figure 10 and Supplemental Information 3, Limulitella is placed within Limulidae,

5 and Yunnanolimulus (?) henkeli is referred to Limulitella henkeli (following Bicknell et al., 2021a). 
